\title{
A Novelty of Perspective of Fikih and PP No. 171965 for Status of Ownership of Life Insurance in Claims Fund
}

\author{
Fuji Rahmadi P., M.A \\ Postgraduate Student, Universitas Islam Negeri (UIN) Medan North Sumatera, \\ Indonesia
}

Lecture of Universitas Pembangunan Panca Budi Medan, North Sumatera, Indonesia

Amiur Nuruddin

Lecture of Universitas Islam Negeri (UIN) Medan, North Sumatera, Indonesia

Nawir Yuslem

Lecture of Universitas Islam Negeri (UIN) Medan, North Sumatera, Indonesia

Received: February 19, 2017 Accepted: May 23, 2017 Published: May 24, 2017

doi: 10.5296/jsss.v4i2.11203 URL: http://doi.org/10.5296/jsss.v4i2.11203

\begin{abstract}
Islam considers insurance or "insured" as a social phenomenon that was ormed by helping each other and humanity. Treasure gained after the death of a person as a result of a cause that by its nature will bring profit, which is done in the period he was still alive then the property as it was by Ibn Hajar al-Haytami, an expert from the Shafi'ites fiqh, in his book Tuhfatul-Muhtaj Syarah Kitab al-Minhaj (by Imam al-Nawawi), fall into the category tirkah treasure. Although the normative existence of insurance is a necessity in the communities in Indonesia but considering Indonesia as a Muslim majority country, then its existence cannot be released by the paradigm of the dynamics of the system of Islamic law. Therefore in this paper describes some of the approaches used in assessing the existence of insurance in Indonesia, it is not enough just to use the normative approach to Islam, but must be coupled with a conventional legal approach that is shaded by the science of law, especially constitutional law.
\end{abstract}


Keywords: Status, Ownership funds, Insurance claim, Fikih

\section{Introduction}

Every human being will have the name calamity, disaster either financially or physically. All the plight of man is the will of God, which cannot be prevented or avoided. However, the calamities that befall humans can be minimized the risk by planting many good deeds for others. Or by dividing the risk to a third party, in this case, the insurance. Sharing the risk with third parties is an effort to lessen the burden on families for the financial risks experienced.

Attempts to minimize the burden of financial risk communities serve as an excuse to gather treasure, either save or registered to institutions that offer insurance. An effort is a form of anticipation, so that later when does death or illness happen to her children that they cannot watch anymore, minimal given the heritage to take care of various needs funerals, for giving the last of his parents, or for the cost of their care when sick. The inheritance parents are deceased's children (heirs) in Islam known as inheritance, which means that the next of kin inherited the treasures people who had died.

Modern human life is so loaded with a variety of threats and hazards, triggered by the weaknesses, mistakes, negligence, and does not understand the difficult problem. Humans cannot know what he'll do tomorrow, and are not aware of the person on earth where he died. The Human each time faced with a series of dangers that threaten life, property, honor, religion and homeland.

Prosperity on Earth can be realized by humans, if humans are capable of understanding and positioning of its existence on the rules that have been determined by his Maker, Allah. To understand and or prove it, then people need to do careful planning in living this life, this plan is not meant to fight destiny, but as a form of business or endeavor to anticipate the undesirable state, a step is the most appropriate one to follow insurance program.

The nature of sharia insurance is mutual responsibility, cooperation or assistance and endure each other. Therefore insurance is allowed by sharia, because the basic principles of sharia invited to everything that resulted from the closeness of the fabric of our fellow human beings and to alleviate something catastrophic them as the word of Allah, in the Qur'an:

"O you who believe! Violate not the sanctity of the Symbols of Allah, nor of the Sacred Month, nor of the animals brought for sacrifice, nor the garlanded people or animals, etc. [Marked by the garlands on their necks made from the outer part of the tree-stems (of Makkah) for their security], nor the people coming to the Sacred House (Makkah), seeking the bounty and good pleasure of their Lord. But when you finish the Ihram (of Hajj or 'Umrah), you may hunt, and let not the hatred of some people in (once) stopping you from Al-Masjid-al-Haram (at Makkah) lead you to transgression (and hostility on your part). Help you one another in Al-Birr and At-Taqwa (virtue, righteousness and piety); but do not help one another in sin and transgression. And fear Allah. Verily, Allah is Severe in punishment." (Al-Ma'idah : 2) or (5. The Table Spread with Food : 2)

In the context of Indonesian life insurance Muslims, in particular, turned out to not only be able to accommodate the needs of Muslims against something suddenly occurred (e.g., death) 
to get insured in the form of money or materials from the company. However, there are some other problems arising from the practice of insurance, among which are life insurance claims funding problems due to the death of someone from the aspect of their ownership status.

Simply put, in the study of Islam can be understood as that fund insurance claim is part of a legacy (tirkah) should be divided among the heirs entitled to receive inheritance by law or agreement faraid each heir. In connection with the above description, there is one case related to the controversy forethought, i.e., as found in Supreme Court Decision No. $97 \mathrm{~K} / \mathrm{AG} /$ 1994 on insurance matters backgrounds their accidental injuries which PT. Prog provide accident insurance compensation to the heirs (deceased's wife) who by the heirs (family of the deceased) demanded the division of compensation because they considered as tirkah for shared inheritance.

\section{Status of Insurance Claims Fund in the Perspective of Jurisprudence}

Study insurance by this research is a life insurance claim funds that will be analyzed regarding assets to be acquired heir disbursed through claims because the product has the sixth death compensation benefits if the participant dies during the agreement. The participation of the participants regarding insuring themselves is an effort made to protect the financial risks will be experienced, especially in the case of death. Because as believed by all forms of life on earth, that death will surely come but do not know when it happened.

Death compensation fund for customers of insurance (which could be called the policyholder), a major program to help alleviate the calamity that occurred on the insured, and insurance companies have joined the bank in trouble disburse the death benefit. The death benefit fund, derived from the money for the results obtained from the management of investment funds by the manager or insurer as the insurer. As noted in a book that "mudaraba is a contract for the property owner who handed over to another group to form a partnership for results."

So the fund is the absolute right of the grantor investment or insurance participants because the money is the money for the results obtained by the deal. And because of that mudharabah, Sheikh Abdul Wahab Khallaf allow insurance practice by stating that the insurer was permissible under the pretext that the insurance is mudharabah. Mudharabah in Islam is "an alliance agreement in profits, with capital provided by the parties and with the power of the other party."

For each client or policyholder who wanted to withdraw funds death, must submit a claim to the insurer, in this case, the insurance company that disbursed the money that has promised to the insured during his lifetime. And this filing can only be done by the heirs designated in the agreement or policy.

For wakalah itself has been mentioned in various books, one of which is al-wajiz which states that "wakalah is the delivery, such as Amra wakkalatu ilaihi - I handed the assignment to him" and there syari'at also by Allah in the Qur'an

Likewise, We awakened them (from their long deep sleep) that they might question one another. A speaker from among them said: "How long have you stayed (here)?" They said: "We have stayed (perhaps) a day or part of a day." They said: "Your Lord (Alone) knows best how long you have stayed (here). So send one of you with this silver coin of yours to the town, and let him find out which is the good lawful food, and bring some of that to you. And let him be 
careful and let no man know of you. (Al-Kahf: 19) or (18. The Cave:19)

Thus, it is clear that the heirs designated in the policy are the belief that the deceased will be given a mandate by the takaful to get a death benefit fund. In addition to the designated heir to represent takaful as an insurer to distribute the gifts to the rightful heir if there are leftovers of the needs of the deceased, began to shroud until it snaps into the grave, paying off debt and fulfill the will of the corpse if any.

\section{Status of Claims Fund Life Insurance Ownership in Perspective PP No. 171965}

Discussion regarding the ownership of this insurance claim funds to first see provisions or rules contained in Law No. 33 of 1964 Jo PP 17 of 1965 as follows:

\section{a. Victims are entitled to compensation}

If any legitimate passengers of public passenger transport equipment which suffered personal injury, caused by the use of public transit, for travelers who are in transit in question, namely when rising from a place of departure to get off at your destination.

\section{b. Double Guarantees}

Public vehicles (buses) is on the ferry, when the ship in the intent accident, the bus passengers who are victims given a double guarantee.

c. Victim whose body are not found

Settlement of compensation for the victims whose bodies have not been found or lost based on the District Court.

Determination of welfare money Prog equated with treasures which are already clearly part of each heir, so there is no different of the rights of each heir that could trigger conflict, means make it goal of establishing Islamic law to provide benefits, goodness, and pleasure for man, The benefits that can realized with the determination of the status of welfare money (fund insurance claims) Prog as inheritance, namely:

a. Rights of the deceased's body on the cost of care is guaranteed because tirkah under Islamic law should put the cost of attention bodies.

b. Rights heir was awake, because in Islamic inheritance law after the rights of deceased fulfilled the rest can divided among the heirs.

c. Status clearer division inheritance for heirs because of the provisions in the life insurance heir accident according to Article 12 of Regulation No. 171965 sequentially as follows:

1) Widows legitimate;

2) In case there is no widow legal, his children were legitimate;

3) In case there is no widow and legitimate children to the parents are legitimate.

d. The benefits for the giver, the achievement of the purpose of administration, because the law of inheritance Islam requires, fulfill the rights deceased on care bodies, wills and debt repayments take precedence after the new wealth divided among heirs, and it is the goal of giving compensation that is for medical expenses and funerals as well as for experts the next of kin.

Damage and ugliness that can avoided on the ownership of insurance funds, namely:

a. Avoid quarrels among heirs, because the division is not clear. Because differences in 
perception can sometimes be a trigger arguments.

b. Prevent diversion of money donation by one of the beneficiaries.

c. Preventing neglect deceased right to receive treatment remains, because in inheritance under Islamic law there are rights that must implemented are: first, care bodies, second, payment of debts, the third, the implementation will, before the inheritance has distributed to heirs.

In addition to the above advantages, the determination of the status of the money (fund claims) Prog as inheritance also has shortcomings, namely:

a. There is a possibility of rights take precedence while liabilities are forgotten by the heirs, since the determination of the compensation money Prog as inheritance is not positive law so that there is no sanction in the country of Indonesia, for those who violate them.

b. If the deceased had a lot of debt, then the rights of the heirs can neglect.

The conclusion that according to PP 17 of 1965, in case the victim dies, the death benefit is given directly to the legal heirs of the victim, namely:

1) Widows or legitimate

2) In case there is no widow authorized, the legitimate children

3) In case there are no widow legal and lawful children, his parents were reasonable

4) In case the victim dies has no heirs, to which organized the funeral given reimbursement of funeral expenses

Then how to put the Government Regulation (PP) No. 17 The year 1965? Clear PP has formulated not oriented to considerations of fiqh, but then be applied to the Religious Courts as the place to use the legal rulings. Therefore, to find a form of it regarding fiqh, need to work longer to find its equivalent in a wide variety of causes in the study of fiqh ownership. Among the reasons, ownership figh is a gift and testament. By reading the sound of the Government Regulation apparently, does not qualify for a prize in fiqh in the real sense. In the PP affirmed that the insurance fund is insured damages. Compensation is clearly different from the title because in between there are fundamental differences. At presents, there are no losers, so it is not a substitute for something. Anything that will.

\section{Conclusion}

The concept of ownership of funds of life insurance claims in the perspective of jurisprudence and PP 17 of 1965 can compare and integrated. First, the comparison. Equation claim ownership of life insurance funds in the view of law and PP 17 of 1965 set by both in substance is the right heir of insurance participants or policyholders according to the provisions in the life insurance Islamic and conventional, both these heirs specified in the insurance policy or not specified in the insurance coverage as well as in relation to insurance soul because of a traffic accident. The difference in the rules PP 17 of 1965 to understand the hierarchy of ownership that the children are legitimate is not eligible to receive funds claim life insurance their parents if their widow living and form of compensation for the death of which the ownership is Individually not a collective, whereas in fiqh there are no hierarchy question and insurance claims fund holdings collectively instead of individually.

Second, integration. The integration process is done by asserting and changing government 
regulations (currently in the form of Regulation No. 17 of 1965) that for the position of heirs who are not designated in the policy or PP 171965 have the same rights in matters of inheritance in the form of fund death benefits are disbursed through the filing of a claim, because the heirs designated only as a fiduciary (representative) on the recommendation (or no recommendation) of the deceased during his lifetime forget the fund from the insurance company.

Through both of ushuliyah simple approach above, to achieve justice and welfare for families left behind, then the funds of life insurance claims should be accepted by one of the heirs (which in PP No. 17 of 1965 referred to his widow) as a fiduciary in a liquefaction a fund (insurance claims) and then distributed to the other heirs.

\section{References}

Ali, H. (2004). Asuransi Dalam Perspektif Hukum Islam. Jakarta: Prenada Media.

Ali, Z. (2008). Hukum Asuransi Syari'ah. Jakarta: Sinar Grafika.

Anshori, A. G. (2008). Asuransi Syariah di Indonesia. Yogyakarta: UII Press.

Antonio, M. S. (1994). Prinsip Dasar Asuransi Takaful dalam Arbitrase Islam di Indonesia. Jakarta: BAMI.

Anwar, K. (2007). Asuransi Syariah Halal dan Maslahat. Solo: Tiga Serangkai.

Anwar, S. (2007). Hukum Perjanjian Syariah Studi tentang Teori Akad dalam Fikih Muamalat. Jakarta: PT RajaGrafindo Persada.

Badrulzaman, M. D. (1983). Mencari Sistem Hukum Benda Nasional. Bandung: Penerbit Alumni.

Basyir, A. A. (2004). Asas-Asas Hukum Muamalat (Hukum Perdata Islam). Yogyakarta: UII Press.

Basyir, A. A. Takaful sebagai Alternatif Asuransi Islam. Ulumul Qur'an, 2/VII/96.

Billah, M. (2001). Ma'sum. Principles and Practices of Takaful and Insuranced Compared. Kuala Lumpur: IIUM Press.

Bradgate, R. (2003). Commercial Law. Butterworth LexisNexis (3rd Edition).

Dahlan, A. A. (Ed.). (1996). Ensiklopedi Hukum Islam. Jakarta: Ikhtiar Baru Van Hoeve.

Dawwabah, A. M. (2008). Meneladani Bisnis Rasulullah. Semarang: Pustaka Rizki Putra.

Depdikbud (1996). Kamus Besar Bahasa Indonesia. Jakarta: Balai Pustaka.

Djamil, F. (1995). Metode Ijtihad Majlis Tarjih Muhammadiyah. Jakarta: Logos.

Haroen, N. (2000). Fiqh Muamalah. Jakarta: Gaya Media Pratama.

Hartono, S. R. (2008). Hukum Asuransi dan Perusahaan Asuransi. Jakarta: Sinar Grafika.

Heykal, N. H. dan M. (2010). Lembaga Keuangan Islam: Tinjauan Teoretis dan Praktis. 
Jakarta: Kencana. https://doi.org/10.20885/millah.vo19.iss2.art11

Ibrahim, J. (2005). Teori dan Metode Penelitian Hukum Normatif. Malang: Bayumedia Publishing.

Komariah, H. P. (2005). Malang: UMM Press.

Lubis, S. K., \& Hukum, E. I. (2000). Jakarta: Sinar Grafika.

Mas'adi, G. A. (2002). Fiqh Mu'amalah Kontekstual. Jakarta: PT. Raja Grafindo Persada.

Muhammad (2004). Ekonomi Mikro dalam Perspektif Islam. Yogyakarta: BPFE.

Muhammad, A. (2006). Hukum Asuransi Indonesia. Bandung: Citra Aditya Bakti.

Muhammad \& Alimin. (2006). Etika dan Perlindungan Konsumen dalam Ekonomi Islam. Yogyakarta: BPFE.

Mujieb, M. A. (1994). Kamus Istilah Fiqh. Jakarta: PT. Pustaka Firdaus.

Muslehuddin, M. (1999). Menggugat Asuransi Modern. Jakarta: Lentera.

Prodjodikoro, W. (1986). Hukum Asuransi di Indonesia. Jakarta: Intermasa.

Purba, R. (1992). Memahami Asuransi di Indonesia. Jakarta: PPM.

Purwosutjipto, H. M. N. (1986). Pengertian Pokok Hukum Dagang Indonesia 6. Jakarta: Djambatan.

Qardhawi, Y. (1997). Norma dan Etika Ekonomi Islam. Jakarta: Gema Insani Press.

Rahman, F. (1975). Ilmu Waris. Bandung: PT. Al-Ma'arif.

Salim, A. (2000). Asuransi dan Manajemen Resiko. Jakarta: RajaGrafindo Persada.

Sanusi, A. (1984). Pengantar Ilmu Hukum dan Pengantar Tata Hukum Indonesia. Bandung: Penerbit Tarsito.

Sastrawidjaja, M. S. (1997). Aspek-Aspek Hukum Asuransi dan Surat Berharga. Jakarta: Alumni.

Shadily, J. M. (1995). Echols dan Hassan. Kamus Inggris Indonesia, Edisi XXI. Jakarta: Cornell University/Gramedia.

Shihab, M. (2007). Quraish. Tafsir Al-Misbah Juz 2. Jakarta: Lentera Hati.

Smith, A. (1903). Wealth of Nation II. Ed. Edwin Cannan. London.

Soekanto, S. (1984). Pengantar Penelitian Hukum. Jakarta: UI Press.

Sofwan, S. S. M. (1981). Hukum Perdata; Hukum Benda. Yogyakarta: Penerbit Liberty.

Solahudin, M. (2006). Lembaga Ekonomi dan Keuangan Islam. Surakarta: Muhammadiyah University Press. 


\section{Macrothink}

Journal of Social Science Studies

ISSN 2329-9150

2017, Vol. 4, No. 2

Subekti, Pokok -Pokok. (1983). Hukum Perdata. Jakarta: Intermasa.

Sudarsono, H. (2004). Bank dan Lembaga Keuangan Syariah Deskripsi dan Ilustrasi. Yogyakarta: Ekonisia.

Suhendi, H. (2010). Fiqih Muamalah. Jakarta: Rajawali Pers.

Sukandy, M. (1985). Syarief. Tarjamah Bulughul Maram. Bandung: PT. Al-Ma’Arif.

Sula, M. S. (2004). Asuransi Syariah (Life And Genera): Konsep dan Sistem Oprasional. Jakarta: Gema Insani.

Sumitro, W. (1996). Asas - Asas Perbankan Islam dan Lembaga - Lembaga Terkait (BMUI dan Takaful) di Indonesia. Jakarta: Raja Grafindo Persada.

Syafe'i, R. (2001). Fiqh Muamalah: Membahas Ekonomi Islam. Bandung: Pustaka Setia.

Syahatah, H. (1998). Ekonomi Rumah Tangga Muslim. Jakarta: Gema Insani Press.

Syahrani, R. (1992). Seluk-Beluk dan Asas-Asas Hukum Perdata. Bandung: Alumni.

Vaughan, E. J. (2003). Vaughan dan Therese. Fundamentals of Risk and Insurance. John Wiley \& Sons, Inc, 9th Edition.

Zahroh, M. A. (1962). Al-Milkiyyah wa Nazhariyatul al'Aqd fi al-Syari'ah al-Islamiyyah. Mesir: Dar al-Fikri al-'Araby.

\section{Copyright Disclaimer}

Copyright for this article is retained by the author(s), with first publication rights granted to the journal.

This is an open-access article distributed under the terms and conditions of the Creative Commons Attribution license (http://creativecommons.org/licenses/by/3.0/). 